VICENTE M. DIAZ

University of Michigan

\title{
Creolization and indigeneity
}

C 0 O M M E

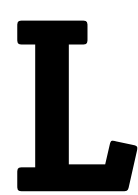

et me begin with a confession that will also serve as a way to situate my commentary. As early as the mid-1980s in graduate school, I bristled when classmates and professors insisted that Indigenous cultural formations that I was studying in the Pacific Islands region were creolizations. In the ensuing decade, I found myself actively resisting cultural studies from the Caribbean as a required model for work that I and colleagues would, nonetheless, champion as a Native Pacific cultural studies, although I always wanted to think that my resistance had more to do with how Caribbean theory had been taken up in academia (e.g., as what was theoretically in vogue) rather than with anything fundamentally wrong with the material itself. Still, the rub, I and other like-minded Pacific Islander scholars felt, had to do with an elision of specifically Indigenous histories, central in Pacific Islands studies, and the marginality of specifically Indigenous Pacific Islander forms of knowledge production in the U.S. academic-industrial complex. Two decades later, Viranjini Munasinghe's strategic purification (this issue) of what turns out to be an interesting and salvageable schizophrenic theory of Caribbean creolization, particularly through her ethnographic material on East Indians in Trinidad, has proven to be a useful if provisional framework for extending, still cautiously, creolization theory to processes of indigenization in the Pacific.

Munasinghe's optimism about the analytical and political value of this homegrown but widely traveled theory of cultural change is noteworthy, given how the theory is predicated on essentializing non-Creole cultural formations and its conflation of pure analytic and ideological registers. What I find useful is-as Sally Engle Merry and Donald Brenneis (2004) have asserted provocatively of Indo-Fijians relative to Native Hawaiians in the Pacific-how the East Indian case in the Caribbean might stand provisionally as an analogy for indigeneity vis-à-vis creolization theory, inasmuch as indigeneity relies historically on cultural mixing to survive, and to the extent that that history can be marshaled as important theoretical and political corrective in its own right. The tactic that makes this compelling, in my opinion, is Munasinghe's insistence on distinguishing

AMERICAN ETHNOLOGIST, Vol. 33, No. 4, pp. 576-578, ISSN 0094-0496, electronic ISSN 1548-1425. (C) 2006 by the American Anthropological Association. All rights reserved. Please direct all requests for permission to photocopy or reproduce article content through the University of California Press's Rights and Permissions website, www.ucpress.edu/journals/ rights.htm. 
between Creole as proper noun and creolization as practice and her upholding of spelling conventions and selfascriptions to be true, as it were, to real-world conventions of differences. In Native Pacific studies, it has become almost customary to underscore the $N$ of Native as a corrective against another historical and cultural effect of colonialism: the conflation between self-identified Native peoples and the nativism of "local" discourses created by settler colonialism. ${ }^{1}$

In her own terms, Munasinghe's approach is to tactically forestall a historical and political effect of theory: the customary slide from "interculturation to acculturation" that happens to Indo-Caribbeans, specifically East Indians in Trinidad, in canonical creolization theory. Her operation is part of a larger task of contextualizing and specifying (by way of historicizing) the theorizing of creolization in the Caribbean specifically to better articulate a more abstracted (she says "pure") form of theorizing creolization. I see her project as a kind of articulated, strategic purity over what is problematic analytically and politically about how some people get to be seen as active products of cultural mixing, whereas others do not, and the theoretical and political implications involved. Munasinghe's approach is to trouble the canonical formulation "mixing = Creole, Creole is native," by demonstrating the processes of cultural mixing (creolization with a small $c$ ) associated with nonCreoles (with a capital $C$ ). I think she is saying something like all people are mixers, although we are not all Mixed, when canonical theory out of the Caribbean seems to be asserting otherwise and seems to do so by historically and politically confusing the analytic and ideological registers of analyses. Her corrective, her way of acknowledging the historical and cultural differences between social subjects and of upholding the important differences between analytical and ideological registers of analyses, is to distinguish between the proper noun (Creole) and the process (creolization).

The purifying, historicizing, refining tactic resonates with chosen strategies of rearticulating indigeneity by, among other things, disarticulating it from other forms of (nonindigenous) nativisms in Native Pacific cultural studies. This analytic and political resonance helps me see what one might call the East Indian "conditions and possibilities" of indigeneity elsewhere at a time when Caribbean theorization continues to hypercirculate through academic practices and institutions as an increasingly preferred model for cultural analyses. Her ethnographic material, as good ethnographic material ought to do, demonstrates the East Indian "case" as a unique local cultural production that is at once engaged and so constituted by the globe without simply being a byproduct of global and other local forces. It is a substantive place of difference and alterity maintained no less by forces of cultural mixing. It has a kind of ontological autonomy, at once independent and interdependent. It creolizes as a way to insist on its difference from Creolization. It is a kind of Native creole, not Creole native. ${ }^{2}$

But the analogy works provisionally. And my concern with this kind of strategic, articulated refinement or purity is not out of fear of purity or abstractness but because of its unwitting complicity in eliding older, aboriginal forms of indigeneity. Part of the problem, I am continually told (not by Munasinghe), is that in the Caribbean region, the aboriginal people of the land are dead, or if they are around, they just do not muster the numbers or the influence to counter narratives of cultural and political existence built on displaced Africans and other Old World travelers. Even in Munasinghe's sharp critique of the nativist desires that underpinned pioneer theorists of creolization in and from the region, the category "native" is that which has come to make a privileged claim to the New World space-place or, in Munasinghe's words "the Creole ... defined native status in the Caribbean." In fairness, this is not her assertion but a description of how the Creole has become the native. It still seems to me that her intervention is to say that the East Indian is also a kind of native (mixer), a move that I can run with for the reasons mentioned above. Still, this is precisely part of the colonial predicament facing Indigenous Pacific Islanders struggling to terminate colonialism in places like Hawai'i, New Zealand, or Guam: how the culturally creative processes of colonialism have also systematically helped sever indigenous or aboriginal peoples from their lands and insert in their places other subject peoples that get to make nativist claims to the locales. If part of Munasinghe's approach to the privileged historical formulation from the Caribbean (Mix = Creole; Creole = native), is to destabilize both by factoring in commensurability (the equation $\mathrm{mix}=$ creole $=$ East Indians $=$ native), it still does not address the question of the status of that other "native," the aboriginal, which we in Native Pacific studies demarcate with the capital $N$. Unfortunately, even her effort to historicize nativist desires that underscore creolization theory's travel beyond the Caribbean does not forestall how the conflation of native with place might play a role in silencing the specifically aboriginal indigenous forms of mixing there, or wherever creolization theory comes to dominate academic discourse. Does aboriginal indigeneity exist in the Caribbean? And can its specific forms of creolization-and let me just call it "Indigenization"-ever come to the fore and inflect theories of creolization, however refined or purified they may be? Must those of us who identify as Indigenous peoples continue to not count unless we theorize with creolization, whether or not it is underscored or capped, but always under the pressure of academic conventions that continue to devalue specifically Indigenous aboriginal modes of being and understanding?

[cultural studies, Pacific studies, Micronesian studies, comparative Native studies, comparative ethnic studies] 


\section{Notes}

1. Criticism of the figure of the "Native" in Pacific Studies is found in Teaiwa 2001. For an emergent "Native Pacific cultural studies" movement, see Diaz and Kauanui 2001. Differences between discourses of indigeneity and other subject formations, both in North America and in the islands, can be found underwriting debates surrounding the emergence of Pacific Islands studies in relation to U.S. ethnic studies. For the trials and tribulations of enjoining Pacific studies with Asian American studies, see Kauanui 2005 and Diaz 2004.

2. Christianity, of course, would be one example of Indigenous creolization, but football can count, too. See Diaz 2002.

\section{References cited}

Diaz, Vicente M.

2002 "Fight Boys till the Last": Football and the Remasculinization of Indigeneity in Guam. In Pacific Diaspora: Island Peoples in the United States and the Pacific. Paul Spickard, Joanne Rondilla, and Deborah Hippolite Wright, eds. Pp. 167-194. Honolulu: University of Hawai'i Press.

2004 To P or Not to P: Marking the Territory between Asian American and Pacific Islander Studies. Journal of Asian American Studies 7(3):183-208.

Diaz, Vicente M., and J. Kehaulani Kauanui, eds.

2001 Native Pacific Cultural Studies on the Edge. Special issue, Contemporary Pacific 31(2).

Kauanui, J. Kehaulani

2005 Asian American Studies and the "Pacific Question." In Asian American Studies after Critical Mass. Kent A. Odo, ed. Pp. 123143. Malden, MA: Blackwell.

Merry, Sally Engle, and Donald Brenneis, eds.

2004 Law and Empire in the Pacific. Santa Fe: School of American Research Press.

Teaiwa, Teresia

2001 Militarism, Tourism, and the Native: Articulations in Oceania. Ph.D. dissertation, Board of Studies in the History of Consciousness, University of California, Santa Cruz.

Vicente M. Diaz

Asian/Pacific Islander American Studies

University of Michigan

3700 Haven Hall

Ann Arbor, MI 48109-1045

vdiaz@umich.edu 